\title{
Legal Analysis of Authority On Military Judges In Judging of Indonesian National Army (TNI)
}

\author{
Sarjono* $^{*}$ and Umar Ma'ruf*) \\ *) Military Police Kodam IV/Diponegoro, E-mail: krisnajono74@gmail.com \\ ${ }^{* *}$ F Faculty Of Law, Universitas Islam Sultan Agung (UNISSULA) Semarang
}

\begin{abstract}
This study aims to find answers to three problems. First, because members of the TNI or TNI soldiers who commit general crimes are not tried in civil courts. Second, the authority of the Military Court to try TNI soldiers who commit general crimes after the enactment of Act No. 34 Th. 2004 regarding the TNI. Third, the obstacles/solutions to law enforcement in prosecuting TNI soldiers after the enactment of the TNI Law. This study uses a normative juridical approach, using primary legal materials and secondary legal materials. The results of the study show that, firstly, TNI members who commit criminal acts are not tried in the Civil Court because there has been no amendment to Act No. 31 of 1997 concerning Military Courts, secondly that after the enactment of Act No.

Keywords: Crime; Military Court; Law on TNI.
\end{abstract}

\section{Introduction}

The concept of Indonesia as a state of law is expressly stated in the provisions of Article 1 paragraph (3) of the 1945 Constitution of the Republic of Indonesia which reads: "The State of Indonesia is a state of law". ${ }^{1}$ So that if there is a violation of the law, then the violator must not be taken to judge him by just anyone. The party entitled to provide protection and settlement is the state, where the state submits it to the judicial power in the form of a judicial body with the executor of which is the judge.

The law has the nature of regulating and forcing everyone to obey order in society and provides strict sanctions (in the form of punishment) for anyone who does not want to obey it. ${ }^{2}$. The purpose of law is to provide protection to the community in the form of legal certainty ${ }^{3}$.

Based on the principle of equality before the law, the position before the law between a person who is a member of the military and civil society is the same, as stated by Moch. Faisal Regards ${ }^{4}$ :

"Although as citizens of the Republic of Indonesia, the army is not a separate class, because each member of the army is also a member of the common people, but

\footnotetext{
${ }^{1}$ Constitution of the Republic of Indonesia 1945

2 Zahri Aeniwati, Sri Kusriyah, Criminal Responsibility towards Criminal of Abortion in Indonesia, Law Development Journal Vo.3 No.1 (2021) url : http://jurnal.unissula.ac.id/index.php/ldj/ article/view/13608/5407

${ }^{3}$ Iin Khaeriyatun Ni'mah, Sukarmi, Analysis On Drug Crime Distribution (G List) Kind of Narcotics (Case Study in Court Decision In Region III Cirebon), Jurnal Daulat Hukum Vo. 2 No.4 (2019) url : http://jurnal,unissula,ac.id/index.php/RH/article/view/8436/3912

${ }^{4}$ Moch. Faisal Salman, Hukum Acara Pidana Militer di Indonesia, Cet II, Mandar Maju, Bandung, 2002, p. 14
} 
because of the burden of the armed forces' obligations as the core in the defense and defense of the state, it is necessary to maintain a more disciplined order in their organization so that it seems as if it is a separate group to achieve/carry out the main objectives of its duties, for that we need a special law and a separate court that is separate from the general court. This statement is in line with what was conveyed by Asep Suherdin and Maryanto that when a member of the military commits a crime, they will still be sentenced without special rights, starting from the process of examination, investigation and prosecution until the court follows the military criminal procedure law. ${ }^{5}$

The legal politics of the judicial system in Indonesia, in which among other things are carried out by the Military Courts, is regulated according to the constitution, bFor Indonesian National Armed Forces (TNI) soldiers themselves, as citizens, all provisions of the existing laws and regulations apply, so any provisions that apply to citizens also apply to TNI soldiers, including the rights and obligations as citizens.

Military courts as regulated in Act No. 31 of 1997 have the authority to adjudicate criminal acts committed by a person who at the time of committing a crime was a soldier, who by law is equated with a soldier, member of a group or service or agency or who is equated or considered as a soldier based on the law and someone who is not included in the three groups but based on the decision of the Commander in Chief with the approval of the Minister of Justice must be tried by a court within the military court. ${ }^{6}$ The rise of general crimes committed by unscrupulous TNI soldiers and the low decision of military courts that hear these cases as well as allegations of several violations of human rights by unresolved soldiers have created public distrust of law enforcement officials and the government. ${ }^{7}$ Including in this case the Military Court institution, so that is a strong reason for the need to amend Act No. 31 of 1997 concerning Military Courts. Reforms in the field of law capture the anxiety of the public who hope that there will be changes to Act No. 31 of 1997 concerning Military Courts so that soldiers who commit general criminal offenses can be tried in general courts. Decree of the People's Consultative Assembly Number VII/MPR/2000 concerning the Role of the Indonesian National Army and the Role of the State Police of the Republic of Indonesia, which among other things regulates ${ }^{8}$ :

- Soldiers are subject to the power of the military courts in the case of violations of the military criminal law and are subject to the powers of the general courts in the case of violations of the general criminal law.

- If the power of the general judiciary as referred to in paragraph (4a) does not function, then TNI Soldiers are subject to judicial authority regulated by law.

\footnotetext{
${ }^{5}$ Asep Suherdin, Maryanto, Analysis of Law Enforcement to Drugs Criminal Art in Military Environment (Case Study In Jurisdiction of Military Court II/09 Bandung), Jurnal Internasional Daulat Hukum Vo. 2 No. 4 (2019) url : http://jurnal.unissula.ac.id/index.php/ RH/article /view/8357/3872

${ }^{6}$ Article 9 paragraph (1) of Law no. 31 of 1997 concerning Military Courts.

${ }^{7}$ Haris Wahyu Sunarso, Akhmad Khisni, Analysis of Criminal Liability as Doer of Preening Criminal (Case Study in the Blora State Court), Jurnal International Daulat Hukum Vo.3 No. 1 (2020) url : http://jurnal.unissula,ac.id/index.php/RH/article/view/8779/4074

${ }^{8}$ Article 3 paragraph (4) MPR Decree No.VII/MPR/2020
} 
This was followed by the enactment of Act No. 34 of 2004 concerning the Indonesian National Army as stated in Article 65 which reads as follows:

- Paragraph (2) Soldiers are subject to the power of the military courts in the case of violations of the military criminal law and are subject to the powers of the general courts in the case of violations of the general criminal law.

- Paragraph (3) If the power of the general judiciary as referred to in paragraph (2) does not function, the soldiers shall be subject to the jurisdiction of the judiciary as regulated by law.

However, until now TNI soldiers who commit general crimes are still being tried in Military Courts. The provisions of Article 3 paragraph (4) of the MPR TAP No. VII/MPR.2020 and the provisions of Article 65 paragraph (2) and (3) of Act No. 34 of 2004 have not been changed because the provisions governing criminal procedural law for military members have not been changed, namely Act No. 31 of 1997 concerning Military Courts. However, to fill this legal vacuum, a solution is provided by the provisions of Article 74 of Act No. 34 of 2004 concerning the Indonesian National Army which reads:

- The provisions as referred to in Article 65 shall apply when the new Law on Military Courts is enacted.

- As long as the new Military Court Law has not been established, it will still be subject to the provisions of Act No. 31 of 1997 concerning Military Court.

Based on the thoughts above, it is interesting to conduct research on why TNI members who commit general crimes are not tried through the Military Courts, know and analyze the authority of the Military Courts in prosecuting TNI members who commit general crimes after the enactment of Act No. 34 of 2004 concerning the TNI, knowing and analyze the obstacles/solutions of law enforcement in prosecuting TNI Soldiers after the enactment of the TNI Law.

\section{Research Methods}

This research is a normative juridical research, using secondary data, using primary legal materials and secondary legal materials. The data obtained were then analyzed using an empirical qualitative method.

\section{Results and Discussion}

\subsection{Because TNI Members Who Do General Crimes Are Not Tried Through Civil (General) Courts}

According to Article 1 number 21 of Act No. 34 of 2004 on the Indonesian National Armed Forces, the Army is a citizen who is prepared and armed for the task of state defense to deal with military threats and armed threats, with the main task of upholding state sovereignty, defending the territorial integrity of the Unitary State of the Republic of Indonesia. which is based on Pancasila and the 1945 Constitution of the Unitary State of the Republic of Indonesia, and protects the entire nation and the entire homeland of Indonesia from threats and disturbances to the integrity of the nation and state. Given this specificity, the legal 
politics of the judicial system in Indonesia as stated in Article 24 paragraph (2) of the 1945 Constitution of the Unitary State of the Republic of Indonesia stipulates that judicial power is exercised by a Supreme Court and the Judicial Body under it in the general court environment, religious courts, military courts, state administrative courts and by a Constitutional Court.

The composition, position, membership and criminal law of the military are regulated in Act No. 34 of 1997 concerning Military Courts. Courts within the scope of military courts have the authority to adjudicate criminal acts committed by a person who at the time of committing a crime was: a) a soldier, b) who by law is equated with a soldier, c) a member of a group or service or agency or who is equated or considered to be a soldier. A soldier based on the law, and d) a person who is not included in the class in letter $a$, letter $b$ and letter $c$ but on the decision of the Commander in Chief with the approval of the minister of justice must be tried by a Court within the Military Court.

Sentencing for a military person is basically an act of education or coaching rather than an act of deterrence or retaliation, as long as the convict will be reactivated into military service after completing his sentence. A military (exconvict) who will return to active duty must become a good and useful military man, both because of his own awareness and as a result of the "educational action" he received while in the Military Correctional Institution. Things like this need to be the basis for judges' considerations to determine whether or not an additional penalty of dismissal is necessary, where this knowledge will not be obtained from judges in the General Court. ${ }^{9}$

Ankum's position as one of the investigators is regulated in Article 69 paragraph (1) of the Law of the Republic of Indonesia Number 31 of 1997 concerning Military Courts which states that investigators are superiors with the right to punish, military police and prosecutors. Ankum's position as an investigator is in accordance with the Unity of Command principle, namely the Commander is fully responsible for the unit and his subordinates, the authority to investigate and investigate criminal acts committed by subordinates who are under the authority of his command is an inherent authority in Ankum, in order to determine the fate of the said subordinates in the settlement of criminal cases whose implementation is delegated to the Military Police Investigator and/or the Prosecutor.

Taking into account this peculiarity, TNI members who commit general crimes are not tried through the General Court (Civil), because it is feared that they can damage the joints of the military, as stated by Lt. Col. Sus Wahyupi, SH, MH. Head of Military Court II-10 Semarang during the interview stated that his opinion that the General Court which handles TNI soldiers who commit general crimes will damage the joints of the military, TNI Soldiers are selected people who are prepared and armed for the task of defending the country, therefore if there is a TNI soldier who commits a violation or crime then have to punish or process is the military itself who knows and understands about the military ${ }^{10}$, because often

\footnotetext{
${ }^{9}$ Sianturi, SR, Hukum Pidana Militer Indonesia, (Jakarta : Babinkum TNI) 2011, p. 69

${ }^{10}$ Results of Interview with Lt. Col. Sus. Wahyupi, SH,MH Head of Military Court II-10 Semarang on June 11, 2021
} 
criminal sanctions in certain crimes are considered not in accordance with the purpose of the crime itself 11 .

So that based on the positive legal provisions that apply by considering the specialties possessed by TNI soldiers, TNI Soldiers who commit general crimes are not tried in the General Court (Civil).

\subsection{The Authority of the Military Courts in Prosecuting TNI Members Who Committed General Crimes Post- The enactment of Act No. 34 of 2004 concerning the Indonesian National Army}

The reform movement in Indonesia has prompted demands for change in various aspects of the life of the nation and state. One of the demands for a fundamental change is the need for a realignment or repositioning of the existence of the Indonesian military, namely the Indonesian National Army and the Indonesian National Police which are integrated into the Armed Forces of the Republic of Indonesia, the repositioning of the TNI and Polri in their development has obtained a strong legal basis through MPR Decree No. VII/MPR/2000 concerning the Role of the TNI and the Role of the Police. The separation of the TNI and Polri institutions was followed by a paradigm shift in the criminal justice system, particularly regarding the jurisdiction of the judiciary over the military who committed general crimes. This paradigm shift can be seen from the provisions of Article 3 paragraph (4) letter a of MPR Decree Number VII/MPR/2000 which states: "TNI soldiers are subject to the power of the Military Courts in terms of violations of military law and submit to the power of the General Courts in violations of general criminal law. ". Furthermore, this provision is reaffirmed by Article 65 paragraph (2) of Act No. 34 of 2004 concerning the Indonesian National Armed Forces which states that: "TNI soldiers are subject to the power of the Military Courts in terms of violations of military law and submit to the power of the General Courts in terms of general violations committed by the military regulated by law".

Based on this provision, judicial jurisdiction over the military who violates the criminal law is given to two different judicial environments, namely the Military Court and the General Court. However, the General Court's jurisdiction over the military who commits general crimes has not yet been implemented due to the transitional provisions in Article 74 of Act No. 34 of 2004 which mandates the establishment of a new Law on Military Courts in lieu of Act No. 31 of 1997, so that during The formation of the new Law on Military Courts has not yet been realized, so the military who commits general crimes remain subject to the jurisdiction of the military courts in accordance with Act No. 31 of 1997.

\subsection{Constraints/Solutions Law Enforcement in Prosecuting TNI Soldiers After the Enactment of the TNI Law}

\footnotetext{
${ }^{11}$ Heru Pramu Apriliyanto, Achmad Sulchan, Implementation of Diversion against Criminal Conduct of Narcotics Conducted by Chilfren, Law Development Journal Vo.3 No. 1 (2021) url : http://jurnal.unissula.ac.id/index.php/ldj/article/view/14240/5457
} 
Law enforcement is the entire activity of the implementers of law enforcement towards law enforcement, justice and protection of human dignity, order, peace, legal certainty in accordance with the 1945 Constitution of the Unitary State of the Republic of Indonesia. ${ }^{12}$ Law enforcement in the country is carried out in a preventive and repressive manner. Preventive law enforcement is held to prevent violations of the law by citizens and this task is generally assigned to executive bodies and the police. Repressive law enforcement is carried out if in the preventive efforts carried out it turns out that there are still violations of the law. In this case, the law must be enforced repressively by law enforcement officers who are given judicial duties. Repressive law enforcement at the operational level is supported and through various institutions that are organizationally separate from one another, but remain within the framework of law enforcement, starting with the Investigating Institution (Polri), Public Prosecutors (Prosecutors) and Court Institutions and ending with Penitentiary . In the Military Courts system, law enforcement begins with investigators, in this case carried out by the Military Police and Superiors with the Right to Punish (Ankum) and the Prosecutor, then Prosecution by the Military Prosecutor by submitting a legal opinion letter and advice on case settlement to the Case Submission Officer (Papera). It then handed over to the Military Court to try the case. Considering that the TNI institution is a state instrument with a very clear chain of command, efforts to prosecute TNI soldiers who commit criminal acts after the enactment of Act No. 34 of 2004 concerning the TNI do not pose significant obstacles, namely continuing to follow the provisions stipulated in Act No. 31 of 1997 concerning the TNI. Military Court pending the issuance of the new Military Court Law.

\section{Closing}

Based on the results of research and discussion, conclusions can be made. First, TNI members who commit general crimes are not tried through the Civil Court because there is no new Law on Military Courts in place of Act No. 31 of 1997 so that TNI members who commit general crimes are still subject to the old regulations, namely Military Courts. Second, after the promulgation of Act No. 34 of 2004 concerning the TNI, the Military Courts still have the authority to adjudicate general crimes, this rule is confirmed in Article 65 paragraph (3) of Act No. 34 of 2004 which states that if the jurisdiction of the General Courts is not functioning, the Soldier TNI who commit criminal acts, both general crimes and military crimes, are tried in the Military Court, Third,

Furthermore, it is recommended, First, it is necessary to encourage the executive and legislative parties to jointly immediately amend Act No. 31 of 1997 concerning Military Courts with a new law so that members of the TNI who commit general crimes can be tried in the Civil Court (general) as mandated by the MPR Decree Number VII/MPR/2000 and Act No. 34 of 2004 concerning TNI. Second, to maintain the dignity of the soldiers of the Indonesian National Army the jurisdiction of Indonesian National Armed Forces soldiers who commit general

${ }^{12}$ Barda Nawawi Arief, Beberapa Aspek Kebijakan Penegakan dan Pengembangan Hukum Pidana, PT. Citra Aditya Bakti, Bandung, 2010, p. 8 
crimes should still be tried by the Military Court. Third, so that law enforcement efforts in prosecuting TNI Soldiers after the enactment of the TNI Law continue to be guided by the existing positive legal provisions.

\section{References}

\section{Journal}

[1] Asep Suherdin, Maryanto, Analysis of Law Enforcement to Drugs Criminal Art in Military Environment (Case Study In Jurisdiction of Military Court II/09 Bandung), Jurnal Internasional Daulat Hukum Vo. 2 No. 4 (2019) url : http://jurnal.unissula.ac.id/index.php/ RH/article /view/8357/3872

[2] Haris Wahyu Sunarso, Akhmad Khisni, Analysis of Criminal Liability as Doer of Preening Criminal (Case Study in the Blora State Court), Jurnal International Daulat Hukum Vo.3 No. 1 (2020) url : http://jurnal.unissula,ac.id/index.php/RH/article/view/8779/4074

[3] Heru Pramu Apriliyanto, Achmad Sulchan, Implementation of Diversion against Criminal Conduct of Narcotics Conducted by Chilfren, Law Development Journal Vo.3 No. 1 (2021) url : http://jurnal.unissula.ac.id Lindex.php/ldj/article/view/14240/5457

[4] Iin Khaeriyatun Ni'mah, Sukarmi, Analysis On Drug Crime Distribution (G List) Kind of Narcotics (Case Study in Court Decision In Region III Cirebon), Jurnal Daulat Hukum Vo. 2 No.4 (2019) url : http://jurnal,unissula,ac.id Lindex.php/RH/article/view/8436/3912

[5] Zahri Aeniwati, Sri Kusriyah, Criminal Responsibility towards Criminal of Abortion in Indonesia, Law Development Journal Vo.3 No.1 (2021) url : http://jurnal. unissula.ac.id/index.php/ldj/article/view/13608/5407

\section{Book}

[1] Barda Nawawi Arief, 2012, Beberapa Aspek Kebijakan Penegakan dan Pengembangan Hukum Pidana, Bandung : PT. Citra Aditya Bakti

[2] Moch. Faisal Salman, 2012, Hukum Acara Pidana Militer di Indonesia, Cet IX, Bandung : Mandar Maju

[3] Ronny Hanintijo Sumitro, 1994, Metodologi Penelitian Hukum, Jakarta : Ghalia Indonesia

[4] Sianturi, SR 2011, Hukum Pidana Militer di Indonesia, Jakarta : Babinkum TNI.

\section{Regulation:}

[1] Constitution of the Republic of Indonesia 1945

[2] MPR Decree No. VI/MPR/2000 concerning the Separation of the Indonesian National Army and the Indonesian National Police

[3] MPR Decree No.VII/MPR/2000 concerning the Role of the Indonesian National Army and the Role of the Indonesian National Police

[4] Act No. 31 of 1997 concerning Military Courts

[5] Act No. 3 of 2002 concerning National Defense

[6] Act No. 4 of 2004 concerning the Indonesian National Army

[7] Act No. 48 of 2009 concerning Judicial Power 